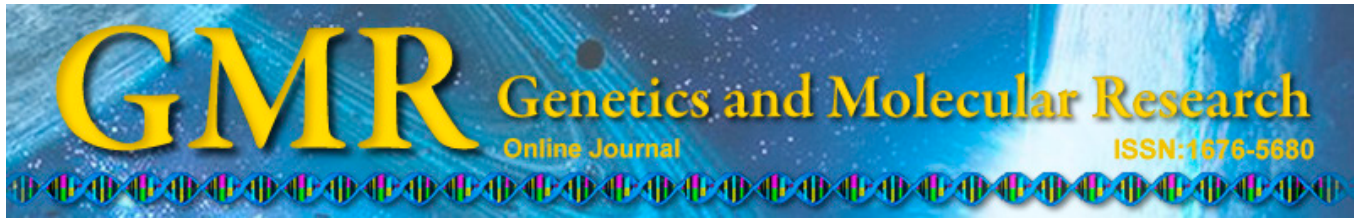

\title{
Ammonia concentration and relative humidity in poultry houses affect the immune response of broilers
}

\author{
F.X. Wei ${ }^{1,2}$, X.F. Hu ${ }^{3}$, B. Xu' ${ }^{2}$, M.H. Zhang ${ }^{1}$, S.Y. Li ${ }^{2}$, Q.Y. Sun ${ }^{2}$ and \\ P. Lin $^{2}$
}

${ }^{1}$ State Key Laboratory of Animal Nutrition, Institute of Animal Sciences, The Chinese Academy of Agricultural Sciences, Beijing, China

${ }^{2}$ Institute of Animal Husbandry and Veterinary Science,

Henan Academy of Agricultural Sciences, Zhengzhou, China

${ }^{3}$ Henan Key Lab of Animal Immunology,

Henan Academy of Agricultural Science, Henan, Zhengzhou, China

Corresponding authors: M.H. Zhang / S.Y. Li

E-mail: zmh66@126.com / 1sy9617@aliyun.com

Genet. Mol. Res. 14 (2): 3160-3169 (2015)

Received February 13, 2014

Accepted October 29, 2014

Published April 10, 2015

DOI http://dx.doi.org/10.4238/2015.April.10.27

\begin{abstract}
To investigate the effect of ammonia $\left(\mathrm{NH}_{3}\right)$ and humidity on the immune response of broilers, broilers were exposed to 30 or 70 $\mathrm{mg} / \mathrm{kg}$ atmospheric $\mathrm{NH}_{3}$ for 21 days. Additionally, birds were exposed to 35,60 , and $85 \%$ relative humidity $(\mathrm{RH})$. The relative weights of lymphoid organs, serum total protein, serum globulin, serum albumin, serum lysozyme, proliferation index of peripheral blood lymphocytes, and splenic cytokine gene expression were determined. Exposure to $70 \mathrm{mg} / \mathrm{kg} \mathrm{NH}$ decreased the relative weight of the spleen during the experimental period, serum lysozyme concentration in the first and second weeks, and serum globulin concentration in the third week. The proliferation of peripheral blood lymphocytes was reduced. High levels of $\mathrm{NH}_{3}$ caused increase in $I L-1 \beta$ gene expression in the experimental period and $I L-4$ gene expression in the first week. Birds exposed to
\end{abstract}


$85 \% \mathrm{RH}$ had lower thymus and bursa of Fabricius weights in the third week and serum lysozyme concentration in the first week; $I L-1 \beta$ and $I L-4$ expressions were higher in the second and third weeks and first and second weeks, respectively, than in birds exposed to $60 \%$ RH. IL-4 expression was lower during the first week, and $I L-1 \beta$ expression was higher during the second week with $35 \% \mathrm{RH}$ than with $60 \% \mathrm{RH}$. In conclusion, high $\mathrm{NH}_{3}$ level in the poultry house suppressed the immune response of broiler chickens. Neither high nor low RH benefited the immune response of broilers. Furthermore, there was an interactive effect between $\mathrm{NH}_{3}$ and $\mathrm{RH}$ on the immune response of broilers.

Key words: Broiler; Ammonia concentration; Relative humidity; Immune response

\section{INTRODUCTION}

During their lifetime, broilers encounter a number of stressors, such as the temperature (Quinteiro-Filho et al., 2012), relative humidity (Yahav et al., 1995), stocking density (Simitzis et al., 2012), immunological challenge (Takahashi et al., 2000), handling (Zulkifli et al., 2000), and airborne contaminants (Do et al., 2005). Of the airborne contaminants, ammonia $\left(\mathrm{NH}_{3}\right)$ is considered to be the most harmful gas released from broiler litter (Carlie, 1984) and is considered detrimental in the modern poultry house (Beker et al., 2004; Miles et al., 2004). Exposure to an excessive amount of $\mathrm{NH}_{3}$ decreases the growth performance of animals (Beker et al., 2004; Miles et al., 2004) and compromises productivity (Deaton et al., 1982; Miles et al., 2004). Additionally, it results in tracheal and pulmonary lesions (Beker et al., 2004), impairs meat and egg quality (Benton and Brake, 2000), and increases animal mortality and morbidity (Beker et al., 2004; Miles, 2004). $\mathrm{NH}_{3}$ in poultry houses also affects immunological function, reducing specific antibody titers (Caveny et al., 1981) and increasing disease susceptibility (Beker et al., 2004). Moreover, the effects of $\mathrm{NH}_{3}$ and other simultaneous stressors are generally additive (McFarlane et al., 1989).

Research has shown that stress delays lymphoid organ development and alters the expression and translation of inflammatory cytokine genes (Zhang et al., 2011). However, there is little documentation on the effects of $\mathrm{NH}_{3}$ exposure or/and relative humidity ( $\mathrm{RH}$ ), two common stressors, on the development of the immune system of broiler chickens. Therefore, we suggest that $\mathrm{NH}_{3}$ exposure may delay the development of lymphoid organs and change the gene expression of inflammatory cytokines, and that these effects may show an interaction with the $\mathrm{RH}$ in the broiler house. We tested the effect of the level of atmospheric $\mathrm{NH}_{3}$ at different levels of RH on the immune system of broiler chickens.

\section{MATERIAL AND METHODS}

\section{Bird husbandry and treatment}

Two hundred and eighty-eight 21-day-old Arbor Acres male broiler chickens with close body weights were allotted into 36 equal pens ( 8 birds/pen) so that the differences in the birds' mean weight for each pen was insignificant. The birds were allotted into 6 equal 
groups of 6 pens with each pen acting as a replicate unit. The basal diet contained $19.5 \%$ crude protein, $0.90 \%$ calcium, $0.40 \%$ available $\mathrm{P}$, and $3.00 \mathrm{Mcal} / \mathrm{kg}$ metabolizable energy on a calculated basis. Birds were kept in programmable artificial climate chambers, with a computercontrolled environment (variability-temperature $\pm 1.0^{\circ} \mathrm{C}, \mathrm{RH} \pm 2.5 \%$ and $\mathrm{NH}_{3} \pm 1 \mathrm{mg} / \mathrm{kg}$ ). Six treatment chambers, holding 6 pens each containing 8 birds, were employed.

The experiment consisted of a $2 \times 3$-factorial design with 2 between-subject factors. The poultry houses contain 2 levels of $\mathrm{NH}_{3}$ concentration, 30 and $70 \mathrm{mg} / \mathrm{kg}$, and 3 levels of $\mathrm{RH}, 35,60$, and $85 \% \mathrm{RH}$. Thus, there were 6 groups: $30 \mathrm{mg} / \mathrm{kg} \mathrm{NH}_{3}+35 \% \mathrm{RH} ; 30 \mathrm{mg} / \mathrm{kg} \mathrm{NH}_{3}$ $+60 \% \mathrm{RH} ; 30 \mathrm{mg} / \mathrm{kg} \mathrm{NH}+85 \% \mathrm{RH} ; 70 \mathrm{mg} / \mathrm{kg} \mathrm{NH}+35 \% \mathrm{RH} ; 70 \mathrm{mg} / \mathrm{kg} \mathrm{NH}_{3}+60 \% \mathrm{RH}$; and $70 \mathrm{mg} / \mathrm{kg} \mathrm{NH}+85 \% \mathrm{RH}$. Anhydrous $\mathrm{NH}_{3}$ was metered continuously in the chambers and maintained at 30 or $70 \mathrm{mg} / \mathrm{kg} \mathrm{NH}$, which was determined daily along with the humidity. During the study, ambient temperature was maintained at $26^{\circ} \mathrm{C}$. All birds were allowed to consume mashed feed and tap water ad libitum, and $24 \mathrm{~h}$ of artificial light was supplied. The experimental period was 21 days, covering 22 to 42 days of age. The experiment was carried out at the State Key Laboratory of Animal Nutrition in Beijing.

\section{Sampling}

At 28, 35, and 42 days of age, 6 healthy birds in each group ( $1 \mathrm{bird} / \mathrm{pen})$ were chosen randomly and weighed. Blood samples were withdrawn from a wing vein and centrifuged at $3000 \mathrm{~g}$ for $10 \mathrm{~min}$ at $4^{\circ} \mathrm{C}$, and the serum was stored at $-80^{\circ} \mathrm{C}$ for further assay. A second blood sample was collected in a 5-mL heparinized tube to determine the peripheral blood lymphocyte proliferation. Then, these birds were slaughtered, and the thymus, bursa of Fabricius (BF), and spleen were collected, and their wet weights and relative weights were recorded. The spleens were washed with $0.1 \%$ diethylpyrocarbonate water, wrapped in sterile and RNase-free foil, rapidly frozen in liquid nitrogen, and stored at $-80^{\circ} \mathrm{C}$ for further analysis.

\section{Analysis}

The relative weights of the lymphoid organs were expressed as lymphoid organ wet weight $(\mathrm{g})$ divided by body weight $(\mathrm{kg})$.

Serum albumin was determined using a kit (Jiancheng, Nanjing, China). Twenty microliters of serum sample was added to $5 \mathrm{~mL}$ bromocresol green colorimetry solution. Ten minutes later, the optical density (OD) of the solutions was measured at $628 \mathrm{~nm}$. Serum total protein was assayed with a kit (Jiancheng, Nanjing, China). Fifty microliters serum, diluted 1:50 with saline, was added to $3 \mathrm{~mL}$ Coomassie brilliant blue solution. The ODs of the mixtures were read at $595 \mathrm{~nm}$ after $10 \mathrm{~min}$. Serum globulin was calculated as total protein minus albumin. Serum lysozyme activity was detected using a kit (Jiancheng). Five milligrams bacterium powder dissolved in $1 \mathrm{~mL}$ bacterium diluent was carefully homogenized and then diluted to $20 \mathrm{~mL}$ in the same diluent. After incubation for $15 \mathrm{~min}$ at $37^{\circ} \mathrm{C}$ followed by $3 \mathrm{~min}$ at $0^{\circ} \mathrm{C}$, the turbidity at $560 \mathrm{~nm}$ was determined.

A 3-[4,5-dimethylthiazol]-2,5-diphenyltetrazolium bromide (MTT) assay was used to determine the peripheral blood lymphocyte proliferation response. The heparinized blood samples were added to isotonic lymphocyte separation medium (density $=1.077$; HaoYang, Tianjin, China). Lymphocytes were isolated after a 30-min centrifugation at $1006 \mathrm{~g}$ at $4^{\circ} \mathrm{C}$. The lymphocyte fraction was collected from the interface and washed 3 times with RPMI 
1640 (Invitrogen, Grand Island, NY, USA) incomplete culture medium. Lymphocytes were then resuspended in $2 \mathrm{~mL}$ RPMI 1640 complete culture medium supplemented with $5 \%(\mathrm{v} / \mathrm{v})$ fetal calf serum, $0.5 \%$ penicillin (final concentration, $100 \mathrm{U} / \mathrm{mL}$ ), $0.5 \%$ streptomycin (final concentration, $100 \mu \mathrm{g} / \mathrm{mL}$ ), and 1\% N-(2-hydroxyethyl)-piperazine-N-2-ethane-sulfonic acid (HEPES, final concentration, 24 mM; Amresco 0511, Amresco, Cleveland, OH, USA). Live cells were counted by trypan blue dye exclusion, and the density of the cells was adjusted to 1 x $10^{7}$ cells $/ \mathrm{mL}$ culture medium.

One hundred microliters cell suspension, and the lymphocyte mitogen concanavalin A (Con A; Sigma, St. Louis, MO, USA) (final concentration $45 \mu \mathrm{g} / \mathrm{mL}$ ) or lipopolysaccharide (LPS; Sigma) (final concentration $25 \mu \mathrm{g} / \mathrm{mL}$ ) was added to a 96-well microtiter plate (Costar 3599, Corning, NY, USA). Cells were then incubated (MCO-18AIC $\mathrm{CO}_{2}$ incubator; Sanyo, Tokyo, Japan) at $37^{\circ} \mathrm{C}$ with $5 \% \mathrm{CO}_{2}$. Sixty-eight hours later, $15 \mu \mathrm{L} 5 \mathrm{mg} / \mathrm{mL}$ MTT was added to each well, followed by a further 4-h incubation. Subsequently, $100 \mu \mathrm{L} 10 \%$ sodium dodecyl sulfate dissolved in $0.04 \mathrm{M} \mathrm{HCl}$ solution was added to each well to lyse the cells and solubilize the MTT crystals; finally, the plates were read using an automated ELISA reader (model 550 Microplate Reader, Bio-Rad Pacific, Hong Kong, China) at $570 \mathrm{~nm}$.

The relative abundance of $I L-1 \beta$ and $I L-4$ mRNAs was determined by quantitative real-time polymerase chain reaction (PCR). The frozen spleen was mashed in a sterile mortar, and the powder was used for total RNA extraction employing a kit (Takara, Dalian, China). The integrity of the RNA was verified by the $\mathrm{OD}$ absorption ratio $2.0>\mathrm{OD}_{260} / \mathrm{OD}_{280}>1.9$ and further by electrophoresis on a $1.0 \%(\mathrm{w} / \mathrm{v})$ ethidium bromide agarose formaldehyde gel.

Reverse transcription was carried out using a kit (Takara). First-strand cDNAs were synthesized from $1 \mu \mathrm{g}$ total RNA using oligo (dT) as primers in the presence of MML-V reverse transcriptase for $5 \mathrm{~min}$ at $20^{\circ} \mathrm{C}, 60 \mathrm{~min}$ at $42^{\circ} \mathrm{C}$, and $5 \mathrm{~min}$ at $70^{\circ} \mathrm{C}$.

PCRs were performed in a volume of $20 \mu \mathrm{L}$ containing $10 \mu \mathrm{L} 2 \mathrm{X}$ SYBR Green PCR Master Mix containing Taq DNA polymerase (Applied Biosystems, Foster City, CA, USA), $2 \mu \mathrm{L}$ cDNA product, reaction buffer, dNTPs, $1 \mu \mathrm{L}$ forward primer, and $1 \mu \mathrm{L}$ reverse primer. The primer sequences used for the cytokine genes and the housekeeping gene $\beta$-actin are shown in Table 1. A standard curve was made as described by Hu et al. (2010). With the determined cycle threshold value and the standard curve, the relative original concentration of target gene and $\beta$-actin was obtained. The target gene relative abundance was expressed as the relative original copy of target gene/the relative original copy of $\beta$-actin. All PCR analyses were performed in triplicate.

Table 1. Gene-specific oligonucleotide primer pairs used for quantitative real-time polymerase chain reaction.

\begin{tabular}{lllcl}
\hline Name & Oligo & Primer sequence & Predicted size (bp) & GenBank accession No. \\
\hline$I L-1 \beta$ & Forward primer & 5'-GGGACTTTGCTGACAGCGACCTG-3' & 128 & NM_204524.1 \\
& Reverse primer & 5'-GTCGAAGGACTGTGAGCGGGTGT-3' & & \multirow{2}{*}{ N-4 } \\
& Forward primer & 5'-GGAGAGGTTTCCTGCGTCAAGAT-3' & \multirow{2}{*}{ NC_006100 } \\
& Reverse primer & 5'-TTCAGGAGCTGACGCATGTTGAG-3' & & \\
\hline
\end{tabular}

\section{Statistical analysis}

Data were analyzed by analysis of variance (ANOVA) with $\mathrm{NH}_{3}$ and $\mathrm{RH}$ in the poultry house as main effects and interactions using the generalized linear model procedure (SPSS 13.0 software for Windows, SPSS Inc., Chicago, IL, USA). One-way ANOVA was also em- 
ployed to analyze the differences between the 6 groups. Differences between mean values were considered to be statistically significant at $\mathrm{P}<0.05$.

\section{RESULTS}

\section{Effect of $\mathrm{NH}_{3}$ and $\mathrm{RH}$ on lymphoid organs of broilers}

As shown in Table 2, exposure to high $\mathrm{NH}_{3}$ concentrations produced a borderline decrease in the relative weight of the spleen on $28(\mathrm{P}=0.065), 35(\mathrm{P}=0.066)$, and 42 days $(\mathrm{P}=$ 0.053). The relative weights of the thymus and $\mathrm{BF}$ were unaffected by the $\mathrm{NH}_{3}$ concentration over the period of the experiment.

\begin{tabular}{|c|c|c|c|c|c|c|c|c|c|c|}
\hline \multirow[t]{2}{*}{ Treatment } & & \multicolumn{3}{|c|}{ First week } & \multicolumn{3}{|c|}{ Second week } & \multicolumn{3}{|c|}{ Third week } \\
\hline & & Thymus & Spleen & $\mathrm{BF}$ & Thymus & Spleen & $\mathrm{BF}$ & Thymus & Spleen & $\mathrm{BF}$ \\
\hline $30 \mathrm{mg} / \mathrm{kg}+35 \%$ & & 0.45 & 0.12 & 0.25 & 0.55 & 0.11 & 0.24 & $0.43^{\mathrm{ab}}$ & $0.10^{\mathrm{ab}}$ & $0.16^{\mathrm{ab}}$ \\
\hline $30 \mathrm{mg} / \mathrm{kg}+60 \%$ & & 0.47 & 0.11 & 0.20 & 0.52 & 0.12 & 0.21 & $0.47^{\mathrm{a}}$ & $0.12^{\mathrm{a}}$ & $0.17^{\mathrm{a}}$ \\
\hline $30 \mathrm{mg} / \mathrm{kg}+85 \%$ & & 0.44 & 0.10 & 0.23 & 0.47 & 0.12 & 0.22 & $0.36^{\mathrm{ab}}$ & $0.10^{\mathrm{ab}}$ & $0.15^{\mathrm{ab}}$ \\
\hline $70 \mathrm{mg} / \mathrm{kg}+35 \%$ & & 0.40 & 0.10 & 0.20 & 0.44 & 0.10 & 0.21 & $0.43^{\mathrm{ab}}$ & $0.09^{\mathrm{ab}}$ & $0.16^{\mathrm{ab}}$ \\
\hline $70 \mathrm{mg} / \mathrm{kg}+60 \%$ & & 0.44 & 0.08 & 0.22 & 0.50 & 0.10 & 0.21 & $0.42^{\mathrm{ab}}$ & $0.11^{\mathrm{ab}}$ & $0.16^{\mathrm{ab}}$ \\
\hline $70 \mathrm{mg} / \mathrm{kg}+85 \%$ & & 0.42 & 0.09 & 0.22 & 0.41 & 0.10 & 0.16 & $0.34^{\mathrm{b}}$ & $0.09^{\mathrm{b}}$ & $0.13^{\mathrm{b}}$ \\
\hline SE & & 0.015 & 0.004 & 0.009 & 0.022 & 0.005 & 0.009 & 0.016 & 0.004 & 0.005 \\
\hline \multirow[t]{2}{*}{ Ammonia } & $30 \mathrm{mg} / \mathrm{kg}$ & 0.45 & 0.11 & 0.23 & 0.51 & 0.12 & 0.22 & 0.42 & 0.11 & 0.16 \\
\hline & $70 \mathrm{mg} / \mathrm{kg}$ & 0.42 & 0.09 & 0.21 & 0.45 & 0.10 & 0.19 & 0.40 & 0.09 & 0.15 \\
\hline \multirow[t]{4}{*}{ Humidity } & $35 \%$ & 0.42 & 0.11 & 0.23 & 0.49 & 0.10 & 0.22 & $0.43^{\mathrm{a}}$ & 0.10 & $0.16^{\mathrm{ab}}$ \\
\hline & $60 \%$ & 0.45 & 0.10 & 0.21 & 0.51 & 0.11 & 0.21 & $0.45^{\mathrm{a}}$ & 0.11 & $0.17^{\mathrm{b}}$ \\
\hline & $85 \%$ & 0.43 & 0.10 & 0.23 & 0.44 & 0.11 & 0.19 & $0.35^{\mathrm{b}}$ & 0.09 & $0.14^{\mathrm{a}}$ \\
\hline & Ammonia level & 0.275 & 0.065 & 0.438 & 0.182 & 0.066 & 0.126 & 0.591 & 0.053 & 0.439 \\
\hline \multirow[t]{2}{*}{$P$ value } & Humidity & 0.723 & 0.276 & 0.552 & 0.388 & 0.865 & 0.322 & 0.040 & 0.142 & 0.080 \\
\hline & Interaction & 0.901 & 0.799 & 0.314 & 0.694 & 0.970 & 0.444 & 0.781 & 0.883 & 0.818 \\
\hline
\end{tabular}

$\mathrm{BF}$, bursa of Fabricius. Different superscript letters in the same column indicate significant differences $(\mathrm{P}<0.05)$.

The RH had no significant effect on the lymphoid organ relative weight in the first and second weeks $(\mathrm{P}>0.05)$. Birds exposed to $85 \% \mathrm{RH}$ for 3 weeks had lower relative weights of thymus $(\mathrm{P}<0.05)$ and $\mathrm{BF}(\mathrm{P}=0.080)$ compared to those exposed to $60 \% \mathrm{RH}$, whereas changes in the spleen were slight and insignificant $(\mathrm{P}>0.05)$ on the third week. Birds exposed to $70 \mathrm{mg} / \mathrm{kg} \mathrm{NH}+85 \% \mathrm{RH}$ had lower relative weights of thymus, spleen, and BF compared with those in $30 \mathrm{mg} / \mathrm{kg} \mathrm{NH}_{3}+60 \% \mathrm{RH}$ by the third week $(\mathrm{P}<0.05)$.

\section{Effect of $\mathrm{NH}_{3}$ and $\mathrm{RH}$ on immunological measures of broilers}

The results in Table 3 show that $\mathrm{NH}_{3}$ and $\mathrm{RH}$ had no effect on serum total protein and albumin $(\mathrm{P}>0.05)$. Moreover, $\mathrm{RH}$ had no effect on globulin $(\mathrm{P}>0.05)$. In the first and second weeks, $\mathrm{NH}_{3}$ had no effect on globulin $(\mathrm{P}>0.05)$, but in the third week, birds that were exposed to $70 \mathrm{mg} / \mathrm{kg} \mathrm{NH}$ had a lower globulin concentration than those exposed to $30 \mathrm{mg} / \mathrm{kg}$ $\mathrm{NH}_{3}(\mathrm{P}<0.05)$. Birds in $70 \mathrm{mg} / \mathrm{kg} \mathrm{NH}+35 \% \mathrm{RH}$ had lower albumin than those in $30 \mathrm{mg} / \mathrm{kg}$ $\mathrm{NH}_{3}+60 \% \mathrm{RH}(\mathrm{P}<0.05)$ during the first week. Birds in $70 \mathrm{mg} / \mathrm{kg} \mathrm{NH}_{3}+85 \% \mathrm{RH}$ had lower albumin than those in $30 \mathrm{mg} / \mathrm{kg} \mathrm{NH}+60 \% \mathrm{RH}(\mathrm{P}<0.05)$ during the third week. Birds in 70 $\mathrm{mg} / \mathrm{kg} \mathrm{NH}+35 \% \mathrm{RH}$ and $70 \mathrm{mg} / \mathrm{kg} \mathrm{NH} \mathrm{NH}_{3}+85 \% \mathrm{RH}$ had lower albumin than those in $30 \mathrm{mg} /$ 
$\mathrm{kg} \mathrm{NH}+60 \% \mathrm{RH}(\mathrm{P}<0.05)$ during the third week. Birds exposed to $70 \mathrm{mg} / \mathrm{kg} \mathrm{NH}$ had a lower lysozyme concentration than those exposed to $30 \mathrm{mg} / \mathrm{kg} \mathrm{NH}_{3}(\mathrm{P}<0.05)$ during the first and second weeks. Birds exposed to $85 \%$ RH had a lower lysozyme concentration than those exposed to $35 \% \mathrm{RH}$ or $60 \% \mathrm{RH}(\mathrm{P}<0.05)$ during the first week. Birds in the $30 \mathrm{mg} / \mathrm{kg} \mathrm{NH}_{3}+$ $60 \% \mathrm{RH}$ group had a higher lysozyme concentration than those in the $70 \mathrm{mg} / \mathrm{kg} \mathrm{NH}+35 \%$ $\mathrm{RH}$ or $70 \mathrm{mg} / \mathrm{kg} \mathrm{NH}_{3}+85 \% \mathrm{RH}$ groups $(\mathrm{P}<0.05)$ during the first week.

\begin{tabular}{|c|c|c|c|c|c|c|c|c|c|c|c|c|c|}
\hline \multirow{2}{*}{\multicolumn{2}{|c|}{ Treatment }} & \multicolumn{4}{|c|}{ First week } & \multicolumn{4}{|c|}{ Second week } & \multicolumn{4}{|c|}{ Third week } \\
\hline & & $\begin{array}{r}\text { Albumin } \\
(\mathrm{mg} / \mathrm{mL})\end{array}$ & $\begin{array}{c}\mathrm{TP} \\
(\mathrm{mg} / \mathrm{mL})\end{array}$ & $\begin{array}{l}\text { Globulin } \\
(\mathrm{mg} / \mathrm{mL})\end{array}$ & $\begin{array}{l}\text { Lysozyme } \\
(\mu \mathrm{g} / \mathrm{mL})\end{array}$ & $\begin{array}{l}\text { Albumin } \\
(\mathrm{mg} / \mathrm{mL})\end{array}$ & $\begin{array}{c}\mathrm{TP} \\
(\mathrm{mg} / \mathrm{mL})\end{array}$ & $\begin{array}{r}\text { Globulin } \\
(\mathrm{mg} / \mathrm{mL})\end{array}$ & $\begin{array}{l}\text { Lysozyme } \\
(\mu \mathrm{g} / \mathrm{mL})\end{array}$ & $\begin{array}{r}\text { Albumin } \\
(\mathrm{mg} / \mathrm{mL})\end{array}$ & $\begin{array}{c}\mathrm{TP} \\
(\mathrm{mg} / \mathrm{mL})\end{array}$ & $\begin{array}{r}\text { Globulin } \\
(\mathrm{mg} / \mathrm{mL})\end{array}$ & $\begin{array}{c}\text { Lysozyme } \\
(\mu \mathrm{g} / \mathrm{mL})\end{array}$ \\
\hline \multicolumn{2}{|c|}{$30 \mathrm{mg} / \mathrm{kg}+35 \%$} & $12.98^{\mathrm{ab}}$ & 29.13 & 16.15 & $4.42^{\mathrm{a}}$ & 17.47 & 38.11 & 20.65 & 2.94 & 22.39 & $31.94^{\mathrm{ab}}$ & $9.44^{\mathrm{b}}$ & 2.76 \\
\hline \multicolumn{2}{|c|}{$30 \mathrm{mg} / \mathrm{kg}+60 \%$} & $14.55^{\mathrm{b}}$ & 31.42 & 16.87 & $4.37^{\mathrm{a}}$ & 17.40 & 37.61 & 20.21 & 2.59 & 25.61 & $35.18^{\mathrm{a}}$ & $9.57^{\mathrm{b}}$ & 2.60 \\
\hline \multicolumn{2}{|c|}{$30 \mathrm{mg} / \mathrm{kg}+85 \%$} & $13.54^{\mathrm{ab}}$ & 30.31 & 16.76 & $3.46^{\mathrm{b}}$ & 15.35 & 35.93 & 20.58 & 2.99 & 24.30 & $30.86^{\mathrm{ab}}$ & $9.05^{\mathrm{b}}$ & 2.21 \\
\hline \multicolumn{2}{|c|}{$70 \mathrm{mg} / \mathrm{kg}+35 \%$} & $12.43^{\mathrm{a}}$ & 28.49 & 15.68 & $3.25^{\mathrm{b}}$ & 17.85 & 32.48 & 17.62 & 2.49 & 25.01 & $30.85^{\text {ab }}$ & $5.84^{\mathrm{a}}$ & 2.35 \\
\hline \multicolumn{2}{|c|}{$70 \mathrm{mg} / \mathrm{kg}+60 \%$} & $13.26^{\mathrm{ab}}$ & 29.34 & 16.08 & $2.98^{\mathrm{bc}}$ & 16.67 & 35.53 & 18.85 & 2.39 & 25.02 & $32.07^{\mathrm{ab}}$ & $7.05^{\mathrm{ab}}$ & 2.30 \\
\hline \multicolumn{2}{|c|}{$70 \mathrm{mg} / \mathrm{kg}+85 \%$} & $13.91^{\mathrm{ab}}$ & 28.67 & 14.76 & $2.52^{\mathrm{c}}$ & 18.96 & 35.20 & 16.24 & 2.32 & 22.50 & $28.83^{b}$ & $6.32^{\mathrm{a}}$ & 2.29 \\
\hline \multicolumn{2}{|l|}{ SE } & 0.263 & 0.581 & 0.481 & 0.083 & 0.873 & 0.848 & 0.909 & 0.057 & 0.679 & 0.734 & 0.342 & 0.077 \\
\hline \multirow[t]{2}{*}{ Ammonia } & $30 \mathrm{mg} / \mathrm{kg}$ & 13.69 & 30.28 & 16.59 & 4.08 & 16.74 & 37.22 & 20.48 & 2.84 & 24.01 & 32.54 & 9.35 & 2.52 \\
\hline & $70 \mathrm{mg} / \mathrm{kg}$ & 13.20 & 28.86 & 15.50 & 2.92 & 17.83 & 34.40 & 17.57 & 2.40 & 24.18 & 30.58 & 6.40 & 2.31 \\
\hline \multirow[t]{3}{*}{ Humidity } & $35 \%$ & 12.70 & 28.84 & 15.93 & $3.83^{\mathrm{b}}$ & 17.66 & 35.30 & 19.27 & 2.72 & 23.70 & 31.34 & 7.47 & 2.55 \\
\hline & $60 \%$ & 13.90 & 30.38 & 16.48 & $3.67^{\mathrm{b}}$ & 17.04 & 36.57 & 19.53 & 2.49 & 25.29 & 33.48 & 8.20 & 2.45 \\
\hline & $85 \%$ & 13.73 & 29.49 & 15.76 & $2.99^{\mathrm{a}}$ & 17.16 & 35.57 & 18.41 & 2.66 & 23.40 & 29.84 & 7.56 & 2.25 \\
\hline \multirow[t]{3}{*}{$P$ value } & Ammonia & 0.357 & 0.222 & 0.268 & $<0.001$ & 0.538 & 0.107 & 0.121 & $<0.001$ & 0.953 & 0.169 & $<0.001$ & 0.183 \\
\hline & Humidity & 0.151 & 0.553 & 0.812 & 0.001 & 0.953 & 0.813 & 0.874 & 0.247 & 0.484 & 0.123 & 0.676 & 0.276 \\
\hline & Interaction & 0.446 & 0.878 & 0.791 & 0.548 & 0.579 & 0.484 & 0.793 & 0.249 & 0.390 & 0.859 & 0.790 & 0.406 \\
\hline
\end{tabular}

Different superscript letters in the same column indicate significant differences $(\mathrm{P}<0.05)$.

As shown in Table 4, RH did not significantly influence the proliferation of peripheral blood lymphocyte in response to Con A or LPS $(\mathrm{P}>0.05)$. It appeared that the proliferation index was significantly linked to $\mathrm{NH}_{3}$ concentration (Table 4), but humidity showed no consistent interaction. The effect of exposure to high levels of $\mathrm{NH}_{3}$ remained constant over the 3 weeks of the experiment.

Table 4. Proliferation of peripheral blood lymphocytes of broilers [stimulus index ( $\mathrm{SI}) ; \mathrm{N}=6$ ].

\begin{tabular}{|c|c|c|c|c|c|c|c|}
\hline \multirow[t]{2}{*}{ Treatment } & & \multicolumn{2}{|c|}{ First week } & \multicolumn{2}{|c|}{ Second week } & \multicolumn{2}{|c|}{ Third week } \\
\hline & & SI (Con A) & SI (LPS) & SI (Con A) & SI (LPS) & SI (Con A) & SI (LPS) \\
\hline $30 \mathrm{mg} / \mathrm{kg}+35 \%$ & & 0.99 & $0.98^{\mathrm{b}}$ & 1.03 & 1.08 & $1.02^{\mathrm{b}}$ & 0.98 \\
\hline $30 \mathrm{mg} / \mathrm{kg}+60 \%$ & & 1.00 & $0.98^{b}$ & 1.02 & 1.05 & $1.01^{\mathrm{b}}$ & 1.00 \\
\hline $30 \mathrm{mg} / \mathrm{kg}+85 \%$ & & 0.99 & $0.96^{\mathrm{ab}}$ & 1.00 & 1.01 & $1.01^{\mathrm{b}}$ & 0.95 \\
\hline $70 \mathrm{mg} / \mathrm{kg}+35 \%$ & & 0.94 & $0.90^{\mathrm{a}}$ & 0.93 & 0.96 & $0.90^{\mathrm{a}}$ & 0.91 \\
\hline $70 \mathrm{mg} / \mathrm{kg}+60 \%$ & & 0.96 & $0.93^{\mathrm{ab}}$ & 0.98 & 0.98 & $0.95^{\mathrm{ab}}$ & 0.94 \\
\hline $70 \mathrm{mg} / \mathrm{kg}+85 \%$ & & 0.93 & $0.92^{\mathrm{ab}}$ & 0.91 & 0.95 & $0.90^{\mathrm{a}}$ & 0.92 \\
\hline $\mathrm{SE}$ & & 0.009 & 0.009 & 0.019 & 0.018 & 0.012 & 0.012 \\
\hline \multirow[t]{2}{*}{ Ammonia } & $30 \mathrm{mg} / \mathrm{kg}$ & 0.99 & 0.97 & 1.02 & 1.04 & 1.01 & 0.98 \\
\hline & $70 \mathrm{mg} / \mathrm{kg}$ & 0.95 & 0.91 & 0.94 & 0.96 & 0.92 & 0.92 \\
\hline \multirow[t]{4}{*}{ Humidity } & $35 \%$ & 0.97 & 0.94 & 0.98 & 1.02 & 0.96 & 0.95 \\
\hline & $60 \%$ & 0.98 & 0.95 & 1.00 & 1.01 & 0.98 & 0.97 \\
\hline & $85 \%$ & 0.96 & 0.94 & 0.95 & 0.98 & 0.95 & 0.93 \\
\hline & Ammonia & 0.011 & 0.001 & 0.038 & 0.025 & $<0.001$ & 0.026 \\
\hline \multirow[t]{2}{*}{$P$ value } & Humidity & 0.637 & 0.658 & 0.624 & 0.641 & 0.601 & 0.486 \\
\hline & Interaction & 0.960 & 0.693 & 0.801 & 0.714 & 0.629 & 0.786 \\
\hline
\end{tabular}

Con A = concanavalin A; LPS = lipopolysaccharide. Different superscript letters in the same column indicate significant differences $(\mathrm{P}<0.05)$. 


\section{Effect of $\mathrm{NH}_{3}$ and $\mathrm{RH}$ on cytokine gene expression of broilers}

The relative mRNA abundance of $I L-1 \beta$ and $I L-4$ in spleen of broilers is shown in Table 5. The results indicate that both $\mathrm{NH}_{3}$ concentration and $\mathrm{RH}$ have effects on the expression of cytokine mRNA in the spleen of birds. Birds exposed to $70 \mathrm{mg} / \mathrm{kg} \mathrm{NH}_{3}$ had a higher mRNA abundance of IL-1 $\beta$ in the first, second, and third weeks than those exposed to $30 \mathrm{mg} /$ $\mathrm{kg} \mathrm{NH}_{3}(\mathrm{P}<0.05)$. The relative mRNA abundance of IL-4 also had the same change as $I L-1 \beta$ in the first week $(\mathrm{P}<0.05)$. In the second week, birds treated with $60 \% \mathrm{RH}$ had a lower mRNA abundance of $I L-1 \beta$ than those treated with 35 or $85 \%$ RH $(\mathrm{P}<0.05)$. In the third week, birds treated with $35 \%$ RH had a higher mRNA abundance of IL- $1 \beta$ than those treated with $85 \%$ RH $(\mathrm{P}<0.05)$. In the first week, birds treated with $60 \%$ RH had a lower mRNA abundance of IL-4 than those treated with $85 \%$ RH and a higher abundance than those treated with $35 \%$ RH $(\mathrm{P}<0.05)$. In the second week, birds treated with $85 \% \mathrm{RH}$ had a higher mRNA abundance of IL-4 than those treated with 35 and $60 \%$ RH $(\mathrm{P}<0.05)$. In the first week, birds in the $30 \mathrm{mg} /$ $\mathrm{kg} \mathrm{NH}_{3}+60 \% \mathrm{RH}$ group had a lower mRNA abundance of $I L-1 \beta$ and $I L-4$ than those in the 70 $\mathrm{mg} / \mathrm{kg} \mathrm{NH}+35 \% \mathrm{RH}$ and $70 \mathrm{mg} / \mathrm{kg} \mathrm{NH}+85 \% \mathrm{RH}$ groups $(\mathrm{P}<0.05)$, as well as $I L-1 \beta$ in the second week $(\mathrm{P}<0.05)$. In the third week, birds in the $30 \mathrm{mg} / \mathrm{kg} \mathrm{NH}+60 \% \mathrm{RH}$ group had a lower mRNA abundance of $I L-1 \beta$ than those in the $70 \mathrm{mg} / \mathrm{kg} \mathrm{NH}_{3}+85 \% \mathrm{RH}$ group $(\mathrm{P}<0.05)$.

Table 5. Relative mRNA abundance of cytokines in spleen of broilers.

\begin{tabular}{|c|c|c|c|c|c|c|c|}
\hline \multirow[t]{2}{*}{ Treatment } & & \multicolumn{2}{|c|}{ First week } & \multicolumn{2}{|c|}{ Second week } & \multicolumn{2}{|c|}{ Third week } \\
\hline & & $I L-1 \beta$ & $I L-4$ & $I L-1 \beta$ & $I L-4$ & $I L-1 \beta$ & $I L-4$ \\
\hline \multicolumn{2}{|l|}{$30 \mathrm{mg} / \mathrm{kg}+35 \%$} & $0.03^{\mathrm{a}}$ & $0.27^{\mathrm{a}}$ & $0.37^{\mathrm{a}}$ & 2.57 & $0.91^{\mathrm{a}}$ & 0.04 \\
\hline \multicolumn{2}{|l|}{$30 \mathrm{mg} / \mathrm{kg}+60 \%$} & $0.03^{\mathrm{a}}$ & $0.60^{\mathrm{a}}$ & $0.36^{\mathrm{a}}$ & 2.76 & $1.42^{\mathrm{ab}}$ & 0.05 \\
\hline \multicolumn{2}{|l|}{$30 \mathrm{mg} / \mathrm{kg}+85 \%$} & $0.06^{\mathrm{b}}$ & $0.75^{\mathrm{ab}}$ & $0.66^{\mathrm{a}}$ & 3.28 & $1.78^{\mathrm{abc}}$ & 0.06 \\
\hline \multicolumn{2}{|l|}{$70 \mathrm{mg} / \mathrm{kg}+35 \%$} & $0.07^{\mathrm{b}}$ & $1.21^{\mathrm{b}}$ & $1.15^{\mathrm{b}}$ & 2.15 & $2.07^{\mathrm{bc}}$ & 0.04 \\
\hline \multicolumn{2}{|l|}{$70 \mathrm{mg} / \mathrm{kg}+60 \%$} & $0.06^{\mathrm{b}}$ & $2.16^{\mathrm{c}}$ & $0.69^{\mathrm{a}}$ & 2.66 & $2.69^{\mathrm{cd}}$ & 0.08 \\
\hline \multicolumn{2}{|l|}{$70 \mathrm{mg} / \mathrm{kg}+85 \%$} & $0.06^{\mathrm{b}}$ & $2.54^{\mathrm{c}}$ & $1.29^{\mathrm{b}}$ & 3.75 & $3.23^{\mathrm{d}}$ & 0.04 \\
\hline \multicolumn{2}{|l|}{ SE } & 0.003 & 0.071 & 0.043 & 0.150 & 0.130 & 0.004 \\
\hline \multirow[t]{2}{*}{ Ammonia } & $30 \mathrm{mg} / \mathrm{kg}$ & 0.04 & 0.55 & 0.46 & 2.87 & 1.37 & 0.05 \\
\hline & $70 \mathrm{mg} / \mathrm{kg}$ & 0.06 & 1.98 & 1.05 & 2.85 & 2.66 & 0.05 \\
\hline \multirow[t]{3}{*}{ Humidity } & $35 \%$ & 0.05 & $0.75^{\mathrm{a}}$ & $0.76^{\mathrm{a}}$ & $2.36^{\mathrm{a}}$ & $1.49^{\mathrm{a}}$ & 0.04 \\
\hline & $60 \%$ & 0.04 & $1.38^{\mathrm{b}}$ & $0.53^{\mathrm{b}}$ & $2.71^{\mathrm{a}}$ & $2.05^{\mathrm{ab}}$ & 0.06 \\
\hline & $85 \%$ & 0.06 & $1.65^{\mathrm{c}}$ & $0.98^{\mathrm{a}}$ & $3.51^{\mathrm{b}}$ & $2.50^{\mathrm{b}}$ & 0.05 \\
\hline \multirow[t]{3}{*}{$P$ value } & Ammonia & $<0.01$ & $<0.01$ & $<0.01$ & 0.956 & $<0.01$ & 0.770 \\
\hline & Humidity & 0.167 & $<0.01$ & $<0.01$ & 0.016 & 0.018 & 0.104 \\
\hline & Interaction & 0.065 & 0.067 & 0.130 & 0.490 & 0.908 & 0.420 \\
\hline
\end{tabular}

Different superscript letters in the same column indicate significant differences $(\mathrm{P}<0.05)$.

\section{DISCUSSION}

It was reported that stress resulted in lymphoid organ (thymus, spleen, and BF) atrophy (Selye, 1998). Some of these effects could only be partly reproduced in this study of broiler chickens, in which $70 \mathrm{mg} / \mathrm{kg} \mathrm{NH}_{3}$ in a poultry house decreased the relative weights of the spleen, but we did not find differences in the relative weights of the thymus and BF between the 70 and $30 \mathrm{mg} / \mathrm{kg} \mathrm{NH}$ groups during the first, second, and third weeks of $\mathrm{NH}_{3}$ exposure. Moreover, in this study, RH had no effect on the relative weight of the spleen; $85 \% \mathrm{RH}$ decreased the relative weights of the thymus and BF in the third week of exposure. Previous reports also had inconsistent results about the effect of stress on the thymus, spleen, and BF 
(Quinteiro-Filho et al., 2010, 2012; Li et al., 2012). Quinteiro-Filho et al. (2010) showed that long-term (7 days) heat stress decreased the relative weights of the thymus, spleen, and BF, and Quinteiro-Filho et al. (2012) also found that acute $(10 \mathrm{~h})$ heat stress had no effect on the relative weights of the same lymphoid organs. However, mycotoxin-induced stress increased the relative weight of the thymus and BF Li et al. (2012). These different results may be due to the type of stressor, its duration and frequency, and the temporal relationship between the stress application and the immune system evaluation (Avitsur et al., 2003; Bartolomucci et al., 2005; Queiroz et al., 2008). In this study, we also found that a high level of $\mathrm{NH}_{3}$ and high $\mathrm{RH}$ had an additive effect on the relative weight of the thymus, spleen, and BF of broiler chickens after long-term exposure (3 weeks).

In this study, a high level of $\mathrm{NH}_{3}$ decreased the serum globulin concentration on the third week, which is partly in agreement with the results of previous research (Javed et al., 1995; Stanley et al., 2004; Gao et al., 2009; Andretta et al., 2012; Li et al., 2012). Moreover, in this study, $\mathrm{NH}_{3}$ and $\mathrm{RH}$ had an additive detrimental effect on albumin, total protein, and globulin. Lysozyme is mainly secreted by phagocytes and is a nonspecific immune effector. In this study, a high level of $\mathrm{NH}_{3}$ decreased serum lysozyme in the first and second weeks, and $85 \%$ $\mathrm{RH}$ had a similar effect in the first week. $\mathrm{NH}_{3}$ and $\mathrm{RH}$ also had an additive detrimental effect on lysozyme. The decreased lysozyme levels in stressed birds suggest that phagocytes were delayed with the stressor of $\mathrm{NH}_{3}$ and $\mathrm{RH}$. Therefore, stresses delay the nonspecific immunity of birds at some level. The lowered serum albumin, total protein, globulin, and lysozyme concentration may be due to damage in hepatocytes and impaired functions, such as amino acid transport and protein synthesis, in stressed broilers (Meissonnier et al., 2005; Faixová et al., 2007).

Antigen- or nonspecific mitogen-induced proliferation of peripheral blood lymphocytes is a good indicator of the initiation of an immune response, which ultimately determines host resistance to disease. Antigen-specific blastogenic assays and lymphocyte proliferation tests provoked by nonspecific mitogens have been used extensively to assess the immunocompetence of poultry (Baxi and Oberoi, 1999; Vickery et al., 1999). In this study, a high level of $\mathrm{NH}_{3}$ decreased the proliferation of peripheral blood lymphocytes. Moreover, $\mathrm{NH}_{3}$ and $\mathrm{RH}$ in a poultry house had an additive detrimental effect on the proliferation of lymphocytes. It was reported that other types of stressors also decreased the proliferation of lymphocytes (Rafai et al., 2000; Swamy et al., 2004; Long et al., 2011). In chickens, it is well known that stress status is associated with increased plasma corticosterone concentrations because corticosterone is the end product of the hypothalamic-pituitary-adrenal (HPA) axis. It has also been established that corticosterone is responsible for many quantitative and qualitative changes in immune function (Shini et al., 2010). Corticosterone inhibits several immune system functions in various species, including lymphocyte proliferation and immunoglobulin production (Munck et al., 1984).

Stress influences the immune response of humans and animals (Lawrence and Kim, 2000; Padgett and Glaser, 2003). Stress activates the HPA axis and the sympathetic-adrenalmedullary axis, resulting in chronic production of glucocorticoid hormones and catecholamines, which, in turn, alters the gene expression of a variety of cytokines by a complicated physiological process (Padgett and Glaser, 2003). In this study, we also found that a high level of $\mathrm{NH}_{3}$ or/and $\mathrm{RH}$ in the poultry house increased the expression of the $I L-1 \beta$ and $I L-4$ genes. It was reported that other types of stressors also could increase the serum level of $I L-1 \beta$ (Dugué et al., 1993; Mekaouche et al., 1994) and the expression of the $I L-1 \beta$ (Bhalla et al., 2002; Shini et al., 2010; Li et al., 2012) and $I L-4$ genes (Wu et al., 2001). Stress stimulated the HPA to 
release corticosterone, and the elevated corticosterone in blood upregulated the expression of cytokine genes in lymphocytes (Shini et al., 2010).

In conclusion, a high level of $\mathrm{NH}_{3}$ and unsuitable ambient $\mathrm{RH}$ in a poultry house delayed lymphoid organ development and the proliferation of peripheral blood lymphocytes, and it decreased the blood lysozyme activities and increased the expression of cytokine genes, such as $I L-1 \beta$ and $I L-4$, of broiler chickens. Moreover, $\mathrm{NH}_{3}$ and $\mathrm{RH}$ had an additive detrimental effect on these parameters.

\section{ACKNOWLEDGMENTS}

Research supported by the Open Research Fund of the State Key Laboratory of Animal Nutrition (\#2004DA125184F1310), the China Agriculture Research System (\#CARS42), and the Research Startup Project for Doctor of Henan Academy of Agricultural Science.

\section{REFERENCES}

Andretta I, Kipper M, Lehnen CR and Lovatto PA (2012). Meta-analysis of the relationship of mycotoxins with biochemical and hematological parameters in broilers. Poult. Sci. 91: 376-382.

Avitsur R, Stark JL, Dhabhar FS, Kramer KA, et al. (2003). Social experience alters the response to social stress in mice. Brain Behav. Immun. 17: 426-437.

Bartolomucci A, Palanza P, Sacerdote P, Panerai AE, et al. (2005). Social factors and individual vulnerability to chronic stress exposure. Neurosci. Biobehav. Rev. 29: 67-81.

Baxi MK and Oberoi MS (1999). Comparative evaluation of cell culture-adapted and chicken embryo-adapted fowl pox vaccine strains. Avian Dis. 43: 16-21.

Beker A, Vanhooser SL, Swartzlander JH and Teeter RG (2004). Atmospheric ammonia concentration effects on broiler growth and performance. J. Appl. Poult. Res. 13: 5-9.

Benton CE Jr and Brake J (2000). Effects of atmospheric ammonia on albumen height and $\mathrm{pH}$ of fresh broiler breeder eggs. Poult. Sci. 79: 1562-1565.

Bhalla DK, Reinhart PG, Bai C and Gupta SK (2002). Amelioration of ozone-induced lung injury by anti-tumor necrosis factor-alpha. Toxicol. Sci. 69: 400-408.

Carlie FS (1984). Ammonia in poultry houses: a literature review. World Poult. Sci. J. 40: 99-113.

Caveny DD, Quarles CL and Greathouse GA (1981). Atmospheric ammonia and broiler cockerel performance. Poult. Sci. 60: $513-516$.

Deaton JW, Reece FN and Lott BD (1982). Effect of atmospheric ammonia on laying hen performance. Poult. Sci. 61: 1815-1817.

Do JC, Choi IH and Nahm KH (2005). Effects of chemically amended litter on broiler performances, atmospheric ammonia concentration, and phosphorus solubility in litter. Poult. Sci. 84: 679-686.

Dugué B, Leppänen EA, Teppo AM, Fyhrquist F, et al. (1993). Effects of psychological stress on plasma interleukins-1 beta and 6, C-reactive protein, tumour necrosis factor alpha, anti-diuretic hormone and serum cortisol. Scand. J. Clin. Lab. Invest. 53: 555-561.

Faixová Z, Faix S, Bořutová R and Leng L (2007). Effect of different doses of deoxynivalenol on metabolism in broiler chickens. Bull. Vet. Inst. Pulawy. 51: 421-424.

Gao J, Zhang HJ, Wu SG, Yu SH, et al. (2009). Effect of Saccharomyces cerevisiae fermentation product on immune functions of broilers challenged with Eimeria tenella. Poult. Sci. 88: 2141-2151.

Hu XF, Guo YM, Huang BY, Zhang LB, et al. (2010). Effect of corticosterone administration on small intestinal weight and expression of small intestinal nutrient transporter mRNA of broiler chickens. Asian Australas. J. Anim. Sci. 23: $175-181$.

Javed T, Dombrink-Kurtzman MA, Richard JL, Bennett GA, et al. (1995). Serohematologic alterations in broiler chicks on feed amended with Fusarium proliferatum culture material or fumonisin B1 and moniliformin. J. Vet. Diagn. Invest. 7: 520-526.

Lawrence DA and Kim D (2000). Central/peripheral nervous system and immune responses. Toxicology 142: 189-201.

Li Z, Yang ZB, Yang WR, Wang SJ, et al. (2012). Effects of feed-borne Fusarium mycotoxins with or without yeast cell 
wall adsorbent on organ weight, serum biochemistry, and immunological parameters of broiler chickens. Poult. Sci. 91: 2487-2495.

Long FY, Guo YM, Wang Z, Liu D, et al. (2011). Conjugated linoleic acids alleviate infectious bursal disease virusinduced immunosuppression in broiler chickens. Poult. Sci. 90: 1926-1933.

McFarlane JM, Curtis SE, Shank RD and Carmer SG (1989). Multiple concurrent stressors in chicks. 1. Effect on weight gain, feed intake, and behavior. Poult. Sci. 68: 501-509.

Meissonnier GM, Oswald IP and Galtier P (2005). Aflatoxicosis in swine - a bibliographic review of clinical cases and experimental data. Rev. Med. Vet. 156: 591-605.

Mekaouche M, Givalois L, Barbanel G, Siaud P, et al. (1994). Chronic restraint enhances interleukin-1-beta release in the basal state and after an endotoxin challenge, independently of adrenocorticotropin and corticosterone release. Neuroimmunomodulation 1: 292-299.

Miles DM, Branton SL and Lott BD (2004). Atmospheric ammonia is detrimental to the performance of modern commercial broilers. Poult. Sci. 83: 1650-1654.

Munck A, Guyre PM and Holbrook NJ (1984). Physiological functions of glucocorticoids in stress and their relation to pharmacological actions. Endocr. Rev. 5: 25-44.

Padgett DA and Glaser R (2003). How stress influences the immune response. Trends Immunol. 24: 444-448.

Queiroz JdeS, Torello CO, Palermo-Neto J, Valadares MC, et al. (2008). Hematopoietic response of rats exposed to the impact of an acute psychophysiological stressor on responsiveness to an in vivo challenge with Listeria monocytogenes: modulation by Chlorella vulgaris prophylactic treatment. Brain Behav. Immun. 22: 1056-1065.

Quinteiro-Filho WM, Ribeiro A, Ferraz-de-Paula V, Pinheiro ML, et al. (2010). Heat stress impairs performance parameters, induces intestinal injury, and decreases macrophage activity in broiler chickens. Poult. Sci. 89: 1905-1914.

Quinteiro-Filho WM, Rodrigues MV, Ribeiro A, Ferraz-de-Paula V, et al. (2012). Acute heat stress impairs performance parameters and induces mild intestinal enteritis in broiler chickens: role of acute hypothalamic-pituitary-adrenal axis activation. J. Anim. Sci. 90: 1986-1994.

Rafai P, Pettersson H, Bata A, Papp Z, et al. (2000). Effect of dietary T-2 fusariotoxin concentrations on the health and production of white Pekin duck broilers. Poult. Sci. 79: 1548-1556.

Selye H (1998). A syndrome produced by diverse nocuous agents. 1936. J. Neuropsychiatry Clin. Neurosci. 10: 230-231.

Shini S, Huff GR, Shini A and Kaiser P (2010). Understanding stress-induced immunosuppression: exploration of cytokine and chemokine gene profiles in chicken peripheral leukocytes. Poult. Sci. 89: 841-851.

Simitzis PE, Kalogeraki E, Goliomytis M, Charismiadou MA, et al. (2012). Impact of stocking density on broiler growth performance, meat characteristics, behavioural components and indicators of physiological and oxidative stress. $B r$. Poult. Sci. 53: 721-730.

Stanley VG, Winsman M, Dunkley C, Ogunleye T, et al. (2004). The impact of yeast culture residue on the suppression of dietary aflatoxin on the performance of broiler breeder hens. J. Appl. Poult. Res. 13: 533-539.

Swamy HV, Smith TK and MacDonald EJ (2004). Effects of feeding blends of grains naturally contaminated with Fusarium mycotoxins on brain regional neurochemistry of starter pigs and broiler chickens. J. Anim. Sci. 82: 2131-2139.

Takahashi K, Mashiko T and Akiba Y (2000). Effect of dietary concentration of xylitol on growth in male broiler chicks during immunological stress. Poult. Sci. 79: 743-747.

Vickery K, Cossart Y and Dixon R (1999). Cellular immune response of ducks to duck hepatitis B virus infection. J. Med. Virol. 58: 19-25.

Wu Z, Turner DR and Oliveira DB (2001). IL-4 gene expression up-regulated by mercury in rat mast cells: a role of oxidant stress in IL-4 transcription. Int. Immunol. 13: 297-304.

Yahav S, Goldfeld S, Plavnik I and Hurwitz S (1995). Physiological responses of chickens and turkeys to relative humidity during exposure to high ambient temperature. J. Therm. Biol. 20: 245-253.

Zhang WH, Jiang Y, Zhu QF, Gao F, et al. (2011). Sodium butyrate maintains growth performance by regulating the immune response in broiler chickens. Br. Poult. Sci. 52: 292-301.

Zulkifli I, Che Norma MT, Chong CH and Loh TC (2000). Heterophil to lymphocyte ratio and tonic immobility reactions to preslaughter handling in broiler chickens treated with ascorbic acid. Poult. Sci. 79: 402-406. 